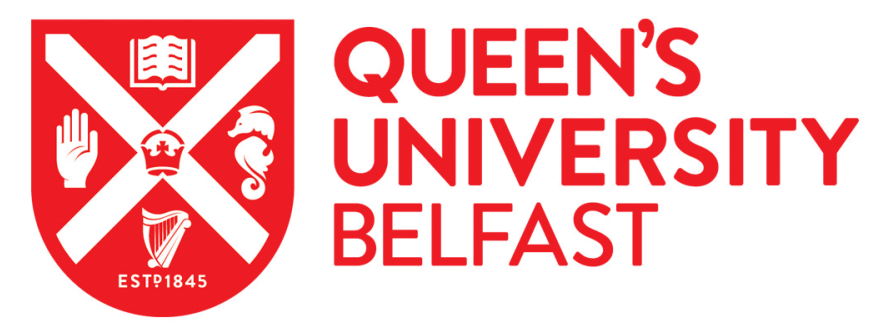

\title{
Between Enabling and provider approach:Key shifts in the national housing policy in India and Brazil
}

\author{
Sengupta, U., Murtagh, B., D'Ottaviano, C., \& Pasternak, S. (2018). Between Enabling and provider \\ approach:Key shifts in the national housing policy in India and Brazil. Environment and Planning C: Politics and \\ Space, 36(5), 856-876. https://doi.org/10.1177/2399654417725754
}

Published in:

Environment and Planning C: Politics and Space

Document Version:

Peer reviewed version

Queen's University Belfast - Research Portal:

Link to publication record in Queen's University Belfast Research Portal

Publisher rights

(c) 2017 The Author.

This work is made available online in accordance with the publisher's policies. Please refer to any applicable terms of use of the publisher.

\section{General rights}

Copyright for the publications made accessible via the Queen's University Belfast Research Portal is retained by the author(s) and / or other copyright owners and it is a condition of accessing these publications that users recognise and abide by the legal requirements associated with these rights.

Take down policy

The Research Portal is Queen's institutional repository that provides access to Queen's research output. Every effort has been made to ensure that content in the Research Portal does not infringe any person's rights, or applicable UK laws. If you discover content in the Research Portal that you believe breaches copyright or violates any law, please contact openaccess@qub.ac.uk. 


\section{Between enabling and provider approach: Key shifts in the national housing policy in India and Brazil}

\section{Introduction}

With the world becoming increasingly urban, the number of slums and squatter settlements has reached new levels. Alarming statistics on the urbanisation and housing poverty has made the metaphor "planet of slums" a global reality. Between 2000 and 2014, cities across the world saw 14\% increase in the number of urban residents living in slums (UN, 2014). Government response to the housing crisis in previous decades is characterised by various approaches constituting public housing (both ownership and rental), sites-and-services, slum upgrading, and other self-help models yielding rather limited levels of success. Since the early 1990s, enabling shelter strategy was advocated as the most promising way of addressing housing challenge posed by rapid urbanisation in global South. Enabling strategy, first articulated in the General Assembly of United Nations in 1988 and was subsequently adopted in the Global Shelter Strategies in 2000 and reiterated in several UN and World Bank reports (UN-Habitat, 1988, 2001, 2003, 2006, 2016; World Bank, 1993). The enabling strategy 
seeks to create enabling housing regimes, that allow markets to produce housing for all, including low-income people and the state taking the back seat to managing the institutional, legislative and regulatory environment. In this sense, enabling is enabling markets to work and protecting them from market failure (Angel, 2000, p.15). The World Bank mainstreamed its application with 'Enabling Housing to Work' (1993) advocating that housing sector should be seen and managed as part of the overall economy. The underlined philosophy was that government should withdraw from direct production of housing or give out subsidies of any form for housing. The strategy was also reinforced by Agenda 21 and Millennium Development Goals (MDGs) which were subsumed into 2030 Agenda for Sustainable Development Goals (SDGs) lending more credence to an inclusive approach to sustainability. Many governments felt the obligation to sign up to the key principles of enabling strategy advocated by these powerful international agencies. Countries such as Brazil and India introduced a raft of reforms to entice the private sector to supply housing for all (including low-income population) in tandem with a gradual withdrawal from public housing. Housing challenges, however, persisted as a large number of people continue to live in slums 
and favelas ${ }^{1}$. We can expect the situation to worsen with the impoverished urban dwellers continuing to face multiple, interlocking disadvantages that relate to all three - social, economic and environmental - dimensions of their lives.

Scholarship over the years has assessed the performance and limitations of enabling housing framework which has progressed through a multitude of localised mutations and adaptations within the respective political structures of the countries. In both Brazil and India, the three decades of policy experiments have generated an inventory of 'empirical examples' through a series of flagship national housing programmes of varying magnitude, scale and subsidy quotient. There appear to be compelling paradoxes that make it opportune to review their housing programmes to explore first, how far enabling strategies have been followed and second, to understand the conceptual similarities in the empirical practices, processes and outcomes. While both Brazil and India provide regional leadership and influence on global housing policy, ultimately they leave their housing challenges unmet. The paper does not intend to

\footnotetext{
${ }^{1}$ After three decades of implementation of enabling strategies, the number of Brazilians living in poor housing conditions has increased from 6.5 million in 2000 to 11.4 million in 2010 whereas in India, number of people living in substandard housing (still over one-third of the country's population) has not gone down.
} 
evaluate these programmes or their outcomes but to capture how different national housing programmes are moving within the broad policy architecture. Where do we stand between the provider or enabling approach? Is there one distinctive model? Both countries have adopted a variety of enabling strategies along with closely intertwined strategies of crisis management and show a clear predisposition towards the provider approach through state-administered, large-scale housing programmes. Next section presents an overview of enabling housing paradigm followed by a review of the government housing programmes in Brazil and India in Section 3. Some conceptual contradictions are discussed in the concluding sections that obscure the international housing policy debate today. The material presented here is derived from an extensive review of the literature and official statistics focused on plans and programmes in Brazil and India as well as contextualising this to the advice being dispensed by international agencies.

\section{Enabling housing paradigm: Coming of an age?}

For a period of nearly three decades, World Bank and UN-Habitat advocated enabling housing paradigm in response to the endemic housing shortage in several parts of global South (Sengupta, 2006; Yap, 2015). Their advice was rooted in the twin 
framework of rescaling the state and enabling the market. The thrust of this framework was to encourage the private sector in delivering housing for all groups leaving the state to a supporting role with timely and appropriate regulatory reforms. Enabling strategy worked well in many countries particularly in gaining rapid economic growth and poverty reduction, but concomitantly saw rising income inequality in terms of per capita income or expenditure (Yap, 2015) widening the gap in housing conditions of the rich and the poor making it somewhat inconsistent with the general thrust of welfarism of the previous era. The process and the outcome of enabling approach are however complex. Three strands of scholarly criticism are seen levelled against it. First, the historical progress has been characterised by lower overall production (Bhan, 2009, Islam, 1996; Sengupta, 2006, Tipple and Korboe, 1998; Yap, 2015) insufficient to filter through to the lower-income segments of the society (Ahmed, 1998; Ogu and Ogbuozobe, 2001; Rondinelli, 1990; Tipple, 1994) or the informal sector (DurandLasserve, 1987; Okpala, 1994). Second, mortgage finance mechanism has shown inherent bias against the urban poor (Choguill, 1997; Smets, 1997; Jones and Ward, 1995; Datta and Jones, 1999; Rahman, 2009; Rolnik, 2013) precluding those working in cash economy and informal sector. Third, and significantly, rising cost of land and housing emerged as the byproduct of both ideological (greater reliance on the profit- 
seeking market, biased finance disbursement) and tectonic (frictions among different groups) standpoints. As an object of academic enquiry, enabling strategy is predominantly framed as an issue of coordination and governance in the context of dramatic unevenness in the distribution of resources in different geographies and institutional structures of urban governance. These scholarships, however, converge at and highlight the inherent inefficiency of the enabling mechanism to see beyond the top percentile of the population (Wakely, 2014). The private sector had channelled its attention to delivering middle and higher-end housing seeking to shore up their own legitimacy gradually gaining absolute control over the housing market abetted by the local and national elites. In the process, the enabling framework actually exacerbated many of the housing problems it ostensibly aspired to resolve such as economic stagnation, quantitative and qualitative housing shortage, unrealistic affordability thresholds and lack of access to formal credit etc. The severity of the damage was such that the 1990s decade became a period during which housing policy 'lost its voice' (Angel, 2000, p.3).

A mid-term review of the two decades of implementation of enabling strategies by UNHabitat (UN-Habitat, 2006) emphasised the global trends of lower housing production, poor targeting and lack of institutional infrastructure. The review did not prompt any 
slowdown in the implementation of the enabling strategy due to its contextual embeddedness within the popular neoliberalist tradition and associated economic arguments (that market was inherently more efficient and effective than the government). A great deal of persuasive writing has however emerged that makes a case for the return of stronger state intervention in housing (Angel, 2000; Mukhija, 2001, 2003, Cao and Keivani, 2015; Yap, 2015). Mukhija (2001), citing examples of slum redevelopment in Mumbai highlighted the paradoxical nature of market mechanism in the Indian context. In and early but an apt reminder of the duality of housing delivery in India, he argues that the Indian government may need to embrace policy contradictions to ensure citizens' rights to housing and to curb apparent developer disinterest to serve the poor within the enabled market environment. A decade later, Cao and Keivani (2014) argue for government intervention to enhance social housing provision and to tighten market regulation as a tool to address both market and government failure ${ }^{2}$. Increasingly, it is recognised that the market-oriented economic reforms have obfuscated the real problems faced by the urban poor as they failed to address the core principles of enablement - transparency and participation in accessing

\footnotetext{
2 This view builds on the emergent trend that began with Chinese government's announcement of one of the largest social housing construction programmes in the world with an initial target of around 36 million units by 2015 (Wang and Shao, 2010) after two decades of intensive housing privatisation, in 2010.
} 
housing and basic services. In response, the past decade has seen a sudden surge of state-administered large-scale housing programmes in many developing countries involving multi-billion dollar investments disbursing sophisticated subsidy packages (Sengupta and Tipple, 2007; Wang and Shao, 2010; UN-Habitat, 2013).

To say that the enabling approach to housing is no longer desirable or viable may be an overstatement. However, the UN-Habitat in its one of the most sincere admissions provides the strongest indication yet of the apparent failure of the enabling strategy: ...in reality, one and the same bias has been at work across the world: middle-class formal home-ownership has been systematically "enabled", but ever-growing numbers of poor citizens have been durably "disabled" from access to adequate housing, remaining confined in single-room or informal housing, not to mention sheer homelessness (World Cities Report, UN Habitat, 2016).

Interestingly, these views emanating from the organisation that has been at the forefront of promoting enabling approach are significant. In this context, the study of Brazilian and Indian housing context not only provides useful insights but also helps to reignite the debate on the dichotomy of enabling vs. provider approach. At the present 
time, it remains to be seen whether housing policies in global South really represent a wholesome adoption of 'enabling framework' or they are an embodiment of both enabling and provider approaches blurring the boundaries of privatization and public investment, deregulation and new regulations where housing policies are continuously evolving.

\section{Government Intervention in Brazil and India}

Government intervention in housing in Brazil and India reveal some interesting trends in response to the massive housing crisis observed in both countries.

\subsection{Brazil: State-local policies and paradigm}

The development trajectory in Brazil in the 1980 and 1990s has been interspersed by debt crisis and the subsequent cumbersome structural adjustment programmes amidst rapid urbanization leading to drastic processes of socio-economic and territorial reorganizations. Such processes generated a growing housing deficit and a sharp rise in favelas. However, favelas in Brazil have a long history of existence, expansion, and unbridled growth amidst variegated policy interventions. Early interventions (up until 
the 1990s), especially in cities such as Rio and São Paulo ${ }^{3}$ were marked by highly centralised clearance policy, relocating squatters to the housing centres at the outskirts of the city. The National Housing Bank (BNH) set up by the military government in 1964, and later renamed as Sistema Financerio da Habitacao or SFH in 1966) showed a wave of highly centralised social housing programmes called 'reformist options' that had produced roughly five million new housing units in a span of 20 years. SFH was the centralised system of housing finance which financed developers, public housing companies (Companhias Habitacionais or COHABS) and Housing Cooperatives (Instituto de Orientacao as Cooperativas Habitacionais of INOCOOPS) throughout the region. BNH had a diverse clientele wider geographic reach. Programmes such as PRÓ-LUZ, PROFAVELA, and PROMORAR focused on urban infrastructure, construction of housing units through direct government subsidy.

With the abolition of the BNH 4 in 1986, the urban and housing sectors saw an institutional vacuum at the federal level. Considered by Valenca (1998) as the 'lost

\footnotetext{
${ }^{3}$ See Pasternak and D'Ottaviano (2014) for details - they have divided the last 30 years of Brazilian housing into eight chronological periods.

${ }^{4}$ Established in 1964, the National Housing Bank or Banco Nacional da Habitação (BNH) operated until it was abolished in 1986 to be replaced by Caixa Econômica Federal. The abolition of the BNH was largely a political move, executed
} 
decade', the 90s decade saw a rapid withdrawal of the national government from housing in tandem with transfer of social housing obligation to the local government. The institutional vacuum in metropolitan areas was all the more dramatic considering the country's relatively urbanised profile when large city regions had been the spatial nodes. Conversely, the reduction of federal programs and regulations opened up an important window for policy innovation by local governments. This was accompanied by the consolidation of democracy with the first free state and municipal elections (in large cities) in 20 years. As a result, several local (mainly municipal) governments started to produce innovative urban policies to face the difficult urban conditions. A key element in this process was the slow but steady expansion of leftwing political parties in local governments between the end of the 1980s and the first years of 2000. As a result plans and programmes in the following decade were dominated by principally two aspects of low-income housing delivery: return of the squatter upgrading and back to the city movement. The former intended to build self-managed and community-built homes as a way to reduce costs and reinforce citizenship ${ }^{5}$. The latter was an ideological

without any resistance from the people or civic society to capitalise on the public resentment of its inefficiency and corruption. The replacement Bank was also brought under control of the President Jose Sarney. (See Bonduki, 2014)

${ }^{5}$ For instance, in Osasco, COPROMO (Cooperativa Pró Moradia de Osasco/Osasco Pro-housing Cooperative) occupied and negotiated a large area of the city and built a housing project with 2,000 units through a community-built housing initiative financed by the São Paulo State Housing and Urban Development Company. 
response to empty buildings in the city centre mainly from the social democratic and left-leaning parties. The argument was that even poor working class population have rights to the city and should be integrated into the urban culture. Between 1991 and 2000 the empty housing stock in the country surged from $15.6 \%$ to $17 \%$ of its total housing stock (Table 1). Empty buildings have continued to provide a viable opportunity to house the urban poor in cities such as Sao Paulo whilst the benevolent state acted as a facilitator in the process by altering legislations and constitutions, suggesting all properties have some social purpose. In Sao Paulo, the municipality policy focused on PROVER (Projeto de Urbanização de Favelas com Verticalização/Project of Squatter Settlement Upgrading with Verticalization) known as the 'Cingapura Project' promoting Apartment style- vertical units (generally 5 to 11 storied, with small units $\left(42 \mathrm{~m}^{2}\right)$ constructed by private developers. Local municipalities such as Diadema proactively identified vacant properties and allocated them for the construction of HIS (Habitação de Interesse Social/Social Interest Housing) through Special Areas of Social Interest (AEIS) I and II in their master plans. However, despite its intellectual and inclusive origin, it showed the hallmark of classic top-down approach without any room for public consultation and government appeared to cherry-pick projects based on political indoctrination. 


\section{Table 1: Empty homes in Sao Paulo and Brazil}

Source: IBGE (1991, 2000 and 2010)

The next decade of Brazilian housing continued to exhibit state-centric pro-people regeneration (of vacant buildings) alongside settlement upgrading policies led by city governments. Social movements and activism became the hallmark of Brazil's housing landscape. In this respect, the innovative and progressive legislation on the so-called 'Statute of the City 2001' is a paradigmatic example. It enabled creation of Ministry of Cities and the National Council of Cities (Fernandes, 2007). The resultant institutional landscape saw rise of pro-active municipal governments taking on the mantle of housing. Between 2001 and 2004 once again Workers Party took over the administration of Sao Paulo, reigniting the discourse on revitalization of empty buildings and a participation of the population as a way of building citizenship. Programmes such as PRI (Programa de Recuperação Integrada/Integrated Recovery Programme) defined areas for urban interventions through the demarcation of ZEIS (Zonas Especiais de Interesse Social/Special Zones of Social Interest). Part of the interventions was also made by the state government through the PAC (Programa de 
Atendimento aos Cortiços/Service Programme for Slums), in part supported by the Federal government through a comprehensive Home Lease Plan - PAR (Plano de Arrendamento Residencial). As a result of these initiatives, the number of takeovers of vacant buildings in the inner city increased. The municipal administration used the Bairro Legal (Cool Neighborhood) Programme as a tool to implement a set of integrated actions in run down neighbourhoods occupied predominantly by low-income population ${ }^{6}$ in order to improve access to public services, greenery and amenities. It differs from the programmes of the previous administrations due to its strong emphasis on integrated action among different municipal agencies and stakeholders including the non-governmental organisations, and civil society. This bottom-up approach enabled low-income people to an extent. As of April 2002, there were approximately 2,866 projects recorded running nation-wide. Upgrading projects geared toward basic sanitation but had difficulties in matching the urban standards of the formal city whereas resettlement into the city centre was criticised for being fragmentary and

\footnotetext{
6 The priority areas for intervention were chosen according to a social exclusion criterion (defined as a situation of collective deprivation, which includes poverty, discrimination, subservience, inequity, non-accessibility, lack of public representation). The Bairro Legal was implemented in the first phase in Capão Redondo, Brasilândia, Lajeado, Jardim Ângela and Grajaú, since they had higher percentage of low-income families ( $15 \%$ or more). In phase two, it was extended to districts of Campo Limpo, Guaianazes, Iguatemi and Anhanguera.
} 
inhibitory to both participation and investments from the dwellers, thus generating new debts whilst the deregularised finance system rarely reached the poor. Especially with the dismantling of the National Housing Bank (BNH) system in 1986 some state and municipal housing initiatives gained visibility, but, with the exception of Sao Paulo state - which set up a housing fund based on a $1 \%$ increase in value-added tax (ICMS Imposto sobre Circulação de Mercadorias e Serviços) - most other schemes were shortlived and targeted at urgent housing situations (Valenca and Bonates, 2010). The enabling housing approach was not capable of achieving a rebalancing of housing order. Instead, it saw a reassertion of social class division.

Minha Casa Minha Vida (MCMV) marks a milestone in the history of Brazilian housing by conceptualising the emphatic return to the direct provision of social housing for the urban poor. Launched by President Lula da Silva in 2009, the programme aimed to build millions of homes for low-income Brazilians making it effectively an affordable housing scheme of national scale based on home ownership. The programme, which translates into "My House My Life," has had investments totalling an outlay of R\$340 billion (US $\$ 180$ billion), delivering more than 4 million homes which include 2.6 million units delivered to low-income households. The Federal government expects more than twenty-five million people to be covered by the programme by 2019 . In 2016, the 
initiative hit a roadblock, when the incoming administration of President Temer announced it was halting the authorisation of the construction of up to 11,000 new housing units. The order had been signed by the Rousseff administration only days before President Rousseff was suspended from office. The president has since toned down his rhetoric and announced new measures to kickstart construction of 600,000 units this year. Notwithstanding the apparent vulnerability of MCMV during times of both political and economic instability, it has shown resilience owing to diversity in approaches and delivery. Amidst the hyper-drive for home ownership through newbuilds and in an apparent fusion of ideas, the Epiringa and Rizkallah Jorge buildings $^{7}$ in Sao Paulo became the first two vacant properties financed under MCMV programme in 2014 and a rare example of rental-subsidy. The Epiringa building (constructed in 1968 for the Federal Labour Court) is being converted into a social housing with 120 one bedroom and studio units. The total cost of refurbishment would be in the order of $\mathrm{R} \$ 11 \mathrm{~m}$ (US $\$ 5.5 \mathrm{~m}$ ). It has been envisaged that beneficiaries pay $\mathrm{R} \$ 15$ (US\$7.5) per month which reflects a subsidy of $1 / 10$ th of the market rent. Whilst, only

\footnotetext{
7 The Rizkallah Jorge building in the city centre was built in the 1940s and was intended as a luxury hotel; instead, it became a company head office. Sixty years on, under the private initiative option of the Residential Leasing Programme, it has been converted into 167 studio apartments measuring 30-40 m2, each with a bed-sitting room, kitchen, bathroom and utility area. The new occupants are low-income families (See, Budds and Teixeira, 2005).
} 
limited proportion of the units under MCMV is expected to come from conversions, by mainstreaming conversions MCMV has legitimised community firepower and incremental housing approach, both important pillars of low-income housing delivery.

At the macro-economic level, neither the ideological underpinnings of the government intervention nor the level of subsidies was questioned despite the fact that the programme was launched during the financial crisis of 2008. Justified as a government correction to market failure, its initial impetus sprang at least as directly from the need to keep Brazil's economy, employment, and wages stable during the recession. However, the programme remained quintessentially social housing and heralded the proverbial return to the state-run public housing of the previous era. Criticisms abounded over steering the subsidy away from beneficiaries to developers that not only manifested in poor design quality but also reduced options. The programme is almost entirely (97\%) in the hands of private promoters (housing construction companies), a measure justified to speed up the process, avoiding the endless procedures adopted by government institutions (Valenca and Bonates, 2010). Since financing limits are preestablished, the values for calculating profits and sales revolve around: i) land value, which is lower in peripheral neighborhoods; ii) lower cost of design achieved using standardised and repetitive designs, in addition to promoting large complexes, in order 
to maximise economies of scale; and iii) production costs, minimised by using secondrate materials. This resulted in rather small (of around $32 \mathrm{~m}^{2}$ ), poor quality housing units at peripheral locations, devoid of critical link between affordability, design, access and mobility. In Rio for example, 53 percent of MCMV units delivered before 2013 were located in the remote Far West Zone (up to four hours from the city). Despite operational challenges MCMV evinces Brazil's increasing and demonstrable predisposition towards social housing for those who cannot afford 'housing' built by private developers. The persistent housing shortage has influenced this trend. According to 2010 census, the housing shortage in Brazil stood at 5.45 million. A further, 11.4 million people lived in favelas, that whilst providing a housing solution during the decades of rapid urbanisation but condensed leading to 'precarious living conditions and violence during the dismantling of housing welfare system' (Rolnik, 2013, p. 1061). 


\section{Figure 1: Different faces of Favelas and corticos in Brazil}

Source: Authors (2016)

\subsection{India: transition to cautious statism in housing}

Government intervention in housing in India during pre-1990 period is characterised by the object of its emphasis rather than the degree of government involvement (Sengupta and Tipple, 2007). Slum or bustee improvement projects took primacy in the period immediately following the independence from British rule. The $1^{\text {st }}$ Five Year Plan called slums a 'national problem' suggesting clearance, but the government soon realised that it neither had the monetary nor the institutional capacity to achieve those goals. Hence, the $2^{\text {nd }}$ Plan recognised upgrading and improvements. The period is also marked with new legislative/institutional building process 8 that included

\footnotetext{
${ }^{8}$ National Building Organisation was created in 1954 to facilitate research in building construction activity. Town and Country Planning Organisation in 1962 to facilitate spatial planning activities across the country. At the state level, various Housing Boards were created during the same period.
} 
internationally maverick ${ }^{9}$ approaches to tenure regularization such as the Calcutta Thika Tenancy Act in Kolkata and Chawls ${ }^{10}$ in Mumbai that benefited thousands of poor. The period between the 1970s and 1990 witnessed state acting as a developer to build public housing alongside upgrading and Sites and Services schemes to address the problem of slums.

The 1990s decade witnessed emergence of decentralisation and liberalisation as the two pillars of governance architecture. Consistent with global trends of democratisation, the dramatic declaration in the $9^{\text {th }}$ Five Year Plan "Housing is State [Government's] subject" was abandoned with the $74^{\text {th }}$ Constitutional amendment, which made Urban Local Bodies (ULBs) responsible for housing and services. This 'decentralisation' turn marks a major departure from the provider regime, which predominantly consisted of hierarchical relations. In line with Bermeo’s (1990, p.368)

\footnotetext{
${ }^{9}$ Thika Tenancy Act 1949 provided regularization of bustees or slum settlements with three tier ownership arrangement. Under this arrangement, bustee dwellers rent space in huts built by Thika tenants on land leased to them by the landowners. The Act confers protection against eviction and that land can be inherited not alienated. The settlements were assured of metered electricity connections. Concepts and Thika and Chawls were non-conformist and idiosyncratic approaches of tenure regularisation, implemented at a time when, internationally, eviction was widespread.

10 Chawls are public or private rental housing built in $19^{\text {th }}$ century by government or private landlords to accommodate the migrants coming from villages due to the rising employment in cotton industry. Chawls are buildings with one room or two room units of not more than $20 \mathrm{~m}^{2}$ attached by a common corridor with shared toilets on each floor.
} 
three phases of democratisation ${ }^{11}$, Indian democratisation ${ }^{12}$ went through a gradual transfer of central powers to local and state governments in the 1990s. The devolved responsibility led to the emergence of a particular kind of housing schemes for the impoverished, which were designed by the centre but required matching funds from state and local governments and implemented by ULBs. Urban Basic Services Scheme (1986), later renamed as Urban Basic Services for Poor (1991), Nehru Rozgar Yojna's Scheme of Housing and Shelter Upgradation (1990) and National Slum Development Programme (1996) were among those. Housing decentralisation did not manifest in the same way as observed in Brazil, however, the centrality of the regional level grew stronger in cases of mega cities Mumbai, Kolkata and Delhi, where the regional governments designed a welfare model with its own strong identity ${ }^{13}$. Across the

\footnotetext{
${ }^{11}$ According to Bormeo (1990, p.368) the breakdown of an authoritarian regime might be regarded as the first (analytical) phase of a democratisation process. The second phase then is the construction of a democratic regime, while the final phase is the consolidation of democracy.

12 In India, democratisation was implemented through Panchayati Raj system as the prime instrument of decentralization. The Indian states were functioning as a federation only at two levels - Union and States. The 73rd amendment strengthens the decentralisation process in India and facilitates powers from the states to the local bodies.

${ }^{13}$ However it should also be noted that these cities have not always promoted welfare interventions as real priorities for the city, despite the considerable budget at disposal. This reflects their attitudes and approach towards city development. For instance, Delhi's approach has been rather heavy-handed toward low-income housing whilst Mumbai has made great efforts to address the problems by way of integration of transfer of development rights etc.
} 
nation, liberalisation policy was introduced with a significant fanfare that led to a paradigmatic shift in housing delivery process. The public-private partnership, regulatory reforms coupled with deregulated finance sector firmly established the government's role as an enabler of housing, with a focus on all-income housing. The National Housing policy, 1994 made explicit recognition to the economic contribution of the housing and construction sector in generating employment. Around 25 new housing finance institutions (HFIs) were set up between 1990 and 2000 (Sahu et al, 2009) to boost lending and construction activities targeted to middle and high-income households. By 2001, 100 per cent FDI was allowed in integrated township development. The neoliberal adjustments continued through to slum programmes in mega cities such as Mumbai. For instance, the SRP (Slum Rehabilitation Programme) was implemented by the Slum Rehabilitation Authority (SRA) first in 1997, which can be described as the precursor of the current slum redevelopment programmes. Nijman (2008) describes SRP as marking a critical shift in the state's role, as a provider of public housing to that of a facilitator of construction of low-income housing by optimising on Mumbai's complex zoning and density regimes to ensure development rights and assuring maximum profits for private builders at virtually no cost to the exchequer. However, the slum population continued to soar putting an upward 
pressure on urban housing shortage. By 2012 urban housing shortage stood at 18.78 million units what was expected to grow at a compound annual rate of 6.6 per cent up to the year 2022. In an apparent reversal of the role, central government would revert to direct provision of housing by initiating a series of pro-poor housing programmes in the next decade as discussed in the following paragraphs.

One of the early and popular centrally-sponsored scheme aimed at benefiting the Slum Dwellers was Valmiki Ambedkar Awas Yojana (VAMBAY). The scheme was primarily aimed at ameliorating the housing problems for the slum dwellers living Below Poverty Line. It provided about INR 3 billion (US $\$ 0.3$ billion) of annual assistance to designated state agencies responsible for implementation. The central government also mandated state governments to use 20 percent of the total allocation under VAMBAY for the National Sanitation Project. Whilst heralded as a success in its initial years, there was geographic bias in their performance largely due to state governments being reluctant to match-fund. Buckley, Singh and Kalarickal (2007) illustrate the State indifference in the use of VAMBAY resources comparing two states, Kerala, and Bihar in 2001-02. The former with 45,000 urban slum dwellers received US $\$ 113$ (INR 5,672) per capita and the latter, with more than 500,000 urban slum 
dwellers received nothing. VAMBAY was subsumed in a new scheme called Integrated Housing and Slum Development Programme (IHSDP).

Perhaps the first post-neoliberal and conceptually important intervention in housing materialised through Jawaharlal Nehru Urban Renewal Mission (JNNURM), launched in 2005. As an integrated programme based on three strands of policy - alignment of urban housing, infrastructure and services, developing urban governance through decentralisation and development of new models of low-income housing in 65 major cities $^{14}$. Despite putting the right foot forward, the JNNURM buckled due to being unabashedly neoliberal which was delivered through the application of twin objectives a)securing economic reforms and b)'private-sector first' approach. The former is evident from the central government making JNNURM conditional on state governments to carry out economic reforms such as reduction of stamp duty rates. The latter has been actively pursued by the funding agencies. For instance, the World Bank which partly finances Urban Reform and Management Project in Karnataka (as

\footnotetext{
${ }^{14}$ Under the JNNURM, the Central government gives grants covering 50 per cent of the project cost for cities with population between one million and four million. For cities with population higher than four million, the Central grant is 35 per cent of the project cost. The remaining funding comes from the state's kitty and the urban local bodies or parstatals. At present, there are 523 projects related to urban infrastructure development that is being implemented in 65 cities across the country.
} 
part of JNNURM) threatened to pull out unless a number of enabling instruments including amendment of legislations (Baindur and Kamath, 2009) was introduced. In sum, the JNNURM reflects a top-down approach with limited participation from the states resulting in just 22 per cent target achieved. Going by the performance of the housing schemes for urban slum dwellers under Basic Services for the Urban Poor (BSUP) scheme and Integrated Housing and Slum Development Programme (IHDSP) — the two sub-missions of the JNNURM, only 0.815 units out of the total 1.442 million sanctioned units between 2005 and 2014 (The Pioneer 2014). The extended period for the Mission to allow for ongoing projects to continue ended in March 2017 and any unfinished projects morphed into respective states' programmes. The poor performance as such defeats the objective of addressing housing needs of the EWS and LIG population that constitutes over $90 \%$ of the population ${ }^{15}$.

\footnotetext{
${ }^{15}$ Income classification has been the basis for means testing for welfare distribution in India for decades. With improving economy, income thresholds are revised. The latest revision shows annual income of up to INR 100,000 to fall in the category of economically weaker section (EWS), according to new criteria formulated by the housing and urban poverty alleviation ministry. Households having income between INR 100,000 and INR 200,000 has been classified as lowincome group (LIG).
} 
The government intervention in slum settlements continued with Rajiv Awas Yojana (RAY), launched in 2013 with the ambition to create slum free cities. The objective of the programme has been to bring existing slums into the formal economic circuit with access to basic amenities and to develop institutional and market mechanisms to tackle shortages in land and housing (Tiwari and Rao, 2016). Quintessentially a slum rehabilitation scheme with a neoliberal twist, RAY could not take off due to overlaps with other schemes and lack of willingness of state governments to secure land for relocation of slum dwellers. In 2015, RAY was replaced by Modi government's flagship programme, Pradhanmantri Awas Yojana (PAY), dubbed 'Housing for All by 2022'. This mission aims to provide central assistance to ULBs and other implementing agencies through states and/or Union Territories for in situ rehabilitation of existing slum dwellers using land as a resource through private participation, interest rate subsidies on loans ${ }^{16}$ for housing EWS and LIG households. Under this programme the government has pledged to construct up to 20 million houses by the year 2022 (essentially aimed at matching the $18.78 \mathrm{~m}$ housing deficit) and according to preliminary estimates, an outlay of INR3 trillion (approximately US\$ 44 billion) has

\footnotetext{
${ }^{16}$ Under this programme all eligible households are provided with a central grant between INR100,000- INR230,000 (US\$1483- US\$3412) depending on locational factors and the loan with interest subsidy of 6.5 per cent payable in 15 years. The amount disbursed through the loan is usually matched by the grant amount.
} 
been allocated to spread over the next seven years. The programme is being rolled out in 2508 cities in 26 states. It was launched with self-aggrandizing posters and adverts glorifying the incumbent Prime Minister Narendra Modi for initiating a panacea for housing. Whilst this is too early to critique the programme, a close scrutiny of ingredients of PAY shows apparent adhockery and inconsistency and their deliveries remain questionable due to supply-side and demand-side challenges. Availability of land will be a major challenge to ensure construction of 10 million houses in urban areas for EWS which will require 57,000 acres of urban land (roughly 50\% of total land in Mumbai). Regulatory infrastructural reforms are still outstanding. Furthermore, capacity of the construction and building material industry to construct 3 million plus units per annum is seriously doubted, as the delivery in the last five years has not exceeded one million. India thus needs to up its output by 10 folds in the next 7-8 years to achieve this new goal. More crucially, the programme designed under enabling principles has excessive reliance on its partners. Banks and civil society are underprepared to disburse the volumes of loans planned for the programme. Demand-side challenges include lack of affordable housing finance for EWS as the government grant 
of INR100,000 (US\$1490) per dwelling, whilst being higher than previous programmes, is a poor reflection of the needs of the poor ${ }^{17}$.

In sum, despite being replete with welfare rhetoric, the centrally-designed programmes in India have hung on to neoliberal qualities especially in creating opportunities for private sector, thus blurring the lines between enabling and provider approach. It can be argued that these programmes have introduced an increasingly commercial and speculative element into urban management and aimed at engineering investmentoriented markets in land, services and municipal debt. Conversely, urban policy in India has been steadily adopting a market-friendly approach for some time with increasing level of subsidy to the poor. Under the JNNURM for instance, $50 \%$ cost of construction of home is GOI subsidy, $12 \%$ is beneficiaries' contribution and remaining $38 \%$ is the state government subsidy. In this respect the new programmes are more consolidation than innovation. According to the $12^{\text {th }}$ Five-year plan $(2012$ - 2017) urban housing shortage in the country stands at 18.78 million units that is expected to grow at a

\footnotetext{
${ }^{17}$ Affordable housing components with PAY relies on diverse arrangement including developer-led redevelopment of slum area, credit-linked subsidy disbursement to EWS and LIG with the government sitting as a guarantor, direct subsidy to parastatal agencies for schemes delivering a minimum of 35\% EWS units and loans for building individual homes for EWS population. Ironically, a scheme promoted as being quintessentially affordable could have wholly targeted to promote home ownership in EWS category. This refutes the principle of positive intervention, as especially, demand coming from EWS far exceeds supply and in this context, government should be seeking to fill the gap in housing supply and limit its intervention solely to EWS/LIG category.
} 
compound annual rate of 6.6 per cent up to the year 2022. India is 33 per cent urban today although several independent studies have projected different figures on urban housing project. As per the 'White Paper - Indian Housing Industry'18, urban housing shortage is expected to reach 34.1 million units by the year 2022. The Industry experts suggest around 30 million units in all categories will be needed to house every Indian, which requires 300 thousand acres of land and half a trillion dollar of investment for 1.5 billion $\mathrm{m}^{2}$ of floorspace to be built. By this account, India needs a multi-fold increase in its housing supply. What is, however, missing from these analyses is the dimension of empty homes and ghost towns that are now becoming a common sight in metro cities in India. This leads to a hypothesis that there might be more house than households in certain areas. The 2011 Census which reported India's household increase from $187 \mathrm{~m}$ in 2001 to $247 \mathrm{~m}$ between in 2011, against the increase in new homes in the market from $250 \mathrm{~m}$ to $331 \mathrm{~m}$ during the same period. This suggests $38 \mathrm{~m}$ new units created for $24 \mathrm{~m}$ new households. Despite this increase in the number of houses, housing problem is not solved as the majority housing shortage in comes from bottom segments of the population. India may soon be forced to follow Brazil's lead on empty properties in urban areas.

\footnotetext{
18 This is based on the recent report by research and consultancy firm RNCOS.
} 


\section{Figure 2: Different faces of Slums and squatter settlements in Indian cities}

Source: Authors

\section{$4 \quad$ International Housing Policy and some policy contradictions}

One of the early and probably most common views on enabling approach (as an offshoot of neoliberalism) within housing studies depicts neoliberalism to be unfavourable to urban poor. Neoliberalism is studied and described for its supposed effects on the poor, characterised by privatisation, deregulation and diminishing welfare benefits and accelerating poverty, increasing the number of households living in slums and favelas around the world. Clearly, a dominant trend emerging from the discussions of various programmes in Brazil and India shows a response to such conditions by the re-engagement of the respective governments in low-income housing delivery. As discussed in the preceding section, the direct supply of housing by the state proved wrong time and again but the practice still continues in both countries. Albeit, we don't call them 'public housing' anymore. They are subsidy-led housing solutions 
intended for the urban poor. Notwithstanding discursive variations exist in terms of what Gilbert (2004) calls 'depth vs. breadth' of subsidy dispensing, ${ }^{19}$ across Brazil and India, there is a consistent trend of reversal of subsidy withdrawal that marks a broader shift from the enabler regime to a provider one (Table 2). For example, the MCMV programme in Brazil has set a high subsidy incidence (between $60 \%$ and $90 \%$ of property value). Projects are approved by the appropriate bodies and sold to Brazilian Federal Saving Bank. India is also steadily raising the subsidy quotient with successive programmes. The recently launched PAY impinges on higher subsidy for success and to some extent, modelled on a public housing schemes, which we argue represent a new generation of 'public housing' for the low-income people. However, we would like to caution that these programmes should be viewed as an open-ended, trial and error process of policy movement, which is still evolving subject to the shrouds of misconceptions set out below.

\section{Table 2 Housing programmes, subsidies and outlay}

Sources: Brazil: United Nations Human Settlements Programme (http://www.myhousemylifebrazil.

\footnotetext{
${ }^{19}$ For instance, projects in India combine cash and credit subsidy that shows greater breadth than Brazil's deeper cash subsidy.
} 
com/; http://www.caixa.gov.br); India: Ministry of Housing and Urban Poverty Alleviation (http://mhupa.gov.in/)

MISCONCEPTION \#1: Impoverished people need complete homes

The contemporary housing programmes in both Brazil and India have a huge emphasis on home ownership. The idea sees 'ownership' enabling households to access formal credit, in turn, bringing low-income homes within the wider financial circuits. However, they rarely appear in such pure forms. Instead, they pose an interesting conundrum - whilst property ownership is a stimulant to investment, a finished and complete home is often difficult to consume by the urban poor with no jobs, income or assets. In other words, housing as a commodity becomes too expensive for the urban poor owing to the imputed costs of the ownership (Wakely, 2014). The claim that poor households as a category are consumers and need complete or finished homes is an implicit reproduction of the middle-class paradigm fueled by the notion that in an overheated property market, homeowners tend to gain the most (Sengupta, 2014; Smets, 
1995). On the contrary, the low-income households ${ }^{20}$ are actually looking for an enclosure that gives them sense of a security and permanence to live as well as to engage in employment opportunities. Ironically, the concept of finished home is still embedded in these modernising projects often achieved through relocation posing problems to both beneficiaries as well as the project. The impact on the former is related to loss of social network that plays a significant role in accessing job or informal credit, whilst the ownership-led programmes do not nurture this. Instead, homeownership actually increases their cost of living, and quite often, turns out unaffordable due to associated costs such as property tax, registration fee, capital gains etc. In a study of Affordable Housing Partnership scheme in Gujrat, Barnhardt et al (2015) found the loss of social capital to be a major driver for more than one-third households to abandon the newly acquired homes and to return to their original location. These projects also face additional financial burden associated with higher subsidies as project costs go up to deliver these 'complete homes'. In India, RAY experienced delays in finding new land leading to cost escalations, which, in turn, meant

\footnotetext{
${ }^{20}$ Our informal interviews with households living in Favelas and slums confirm this view. Both researchers from Sao Paulo and India team have conducted interviews in their cities/sites.
} 
housing was not delivered on the required scale and became unaffordable to the target beneficiaries. Conversely, shoots of innovations have been witnessed in Brazil, with "tenant-based" housing subsidies for reusing such vacant properties, as especially, with the landmark decision to fund the Epiranga project with MCMV, the concept of 'incremental housing' has been brought to the mainstream. Incremental housing, , considered a viable splinter of housing supply received much attention internationally with Architect Alejandro Aravena's popular concept of building only the physical foundations, walls, stairs, kitchen and bathrooms of the homes. In India, slum and squatter population have been known to take this approach. De Soto's (2000) thesis that homeownership will eradicate urban poverty in global south brought some enthusiasm to what the World Bank and UN-Habitat had been preaching for decades (through their land titling and ownership programmes in the global South) but these ownership projects rarely met their full objectives

MISCONCEPTION \#2: Government promoting housing policy (not economic policy)

Housing programmes in both countries continue to be economic-driven. Enabling housing framework is rooted to economic rationality - the dominant form of 
rationality - which invaded the world during the neoliberal structuring of the 1980s. Following the debt crisis, governments in the developing countries were subsequently transformed as the agents of the global capital market and were mobilised to institutionalise the private housing market. Government intervention in both Brazil and India can be accused of aiming to hit too many targets. Larger housing deficit coupled with economic debts force governments to explore multiple gains from these state-initiated housing projects. No housing policy, especially since the advent of neoliberalism, has been developed as a 'housing policy' of its own. They are rather molded within a broader economic framework of the government 'to partner with and respond to, the needs of the market, infrastructure development, and even welfare are corollaries of this'(Sud, 2017). This notion is embedded in the approach that sees subsidies directed to financing new, complete homes as economic 'assets' or 'products' that can activate the construction and finance sector. Housing is both means and the end product rolled into one, which makes it a perfect tool to achieve multiple advantages. Low-income homes are delivered by the state as commodified assets so that it can help to maintain broader market and social equilibrium serving two goals: to encourage market ownership of low-income housing in the long run and to resist perpetuating of welfare function of housing as a social good. On this basis, it can be 
argued that through ownership drive the state seeking to pursue economic policy rather than housing policy. In Brazil, the MCMV Programme was launched amidst an economic crisis aimed at tackling two distinct issues: lower the housing deficit and to boost the construction industry. The programme undoubtedly warmed up the Brazilian construction market by encouraging competition for land and skilled construction workers. However, the booming construction market soon created a labour shortage and hiked the construction costs, eventually requiring greater subsidies from the federal government. In India, the real estate sector is a major component of the Indian economy which contributed to $6.3 \%$ of the GDP in 2013/14, at an estimated INR3.7 trillion (US $\$ 55$ billion) (CREDAI, 2013). In both Brazil and India, we have observed a strong inclination towards low-income public housing to form a housing safety net during this economic transition. This, we argue with time, will gain permanence. But this requires a general understanding and reconfiguration of economic and social policies that could integrate with the national housing system more effectively. 
MISCONCEPTION \#3: Government has created conditions for effective private sector operation

The idea of efficient privatised urban government delivering low-income housing implies housing poverty is internalised into the market mechanism. Enabling private sector to provide for the poor continues its primacy in the plans and programmes in both countries. What is, however, problematic is the zealous pursuit without creating conditions for it. The drive towards home ownership, complete homes, and economic goals together, hint at greater financial outlay to deliver new homes and as a consequence, a need to rely on the private capital. However barring few projects that were designed under PPP principle, conditions to attract private capital are still outstanding. For instance, in India, this relates to slow and uneven progress in the several aspects of regulatory reforms. The slow progress in reforming the Rent Control Act has persisted despite explicit recognition from influential programmes such as JNNURM identifying it as a bottleneck for reform and recommending four-point plan to address it. Likewise, the much-maligned ULCRA has been repealed, but as Ahluwalia et al (2013) claim, reform has been deceptive as all cases that are in the court continued to be governed by the earlier Act. Amendments of city Master Plans to include 
unauthorised settlements has been even slower as Bhan (2009) argues progressive city governments such as Delhi have continued to ignore the alleged 'blackspots' in the periphery causing uncertainty over land availability in the city fringes. Likewise, reform on the permit system continues to be slow and uneven (Sengupta, 2013). Ram and Needham (2016) argue even with the existing rules developers could build affordable homes for EWS/LIG, but they are not doing so due to the complexity and rigidity of the existing registration and permit system. Owing to the high transaction cost and rising labour costs coupled with the current capacity of the construction industry, housing delivery to the scale set by these programmes within a short timeframe is seriously questionable. The capacity of the implementation authorities is similarly ignored. For the ULBs, several challenges were identified in reform implementation. These include the complexities relating to certain policy reforms (e.g. property tax and user charges for basic services), the challenge of implementing both reforms together with projects, weak capacity of ULBs, and the lack of funding for reforms. Under JNNURM for instance, the ULBs were dependent on the state's reforms in order to release agreed funds resulting in delays in project implementation (Sharma, 2013). The 'one-size-fits-all' approach of demanding that all states and ULBs achieve 23 reforms within seven years regardless of their stage of development, capacity and financial status, was 
overambitious (Thornton, 2011). While India remains a prime example of regulatory barriers asphyxiating private sector involvement, Brazil provides insights into pitfalls of rapid deregulation and inability to manage the change. The lack of regulation in the real-estate market has unleashed speculation, increasing property values in city centres, which has pushed social housing projects (such as MCMV) to the outskirts of cities. In addition, very few developers are able to compete in the system as the scale of the projects demand a high amount of initial capital-inevitably creating a monopoly. To create a private sector-enabling environment that is conducive to increasing social housing supply is thus a far more complex undertaking than just providing the basic market institutions.

MISCONCEPTION \#4: Sufficient participation and enablement at local level

As explained in the earlier narratives, it is clear that decentralisation is central to providing a new context within which low-income housing in Brazil and India is emerging. More precisely, decentralisation is taking place in the context of neoliberal national macroeconomic environment. Whilst the concept is unproblematic as 
decentralised systems of housing delivery involving market actors, government agencies and NGOs is set against the general context of neoliberalism, without adequate empowerment of local actors, the process breeds ambivalence and inconsistency. For instance, the flagship programmes both in India and Brazil have ignored their inherent weakness, which relates to lack of understanding of the capacity at the local level. Higher goals set by these programmes (such as legislative reforms) are beyond the capacity of the implementing bodies There appears to be a distinct disillusionment with the concept of decentralisation and its ability to run in tandem with the government conceptualisation of housing delivery at the local level. In India, Tiwari and Rao (2016) contend that while most of these programmes are well intended in terms of their housing decentralisation objectives, they could not deliver much due to lack of financial resources at local level, excessive dependency on the central government for funds leading to sustenance of the top-down approach, with poor participation from the state governments, marginal inputs from the operational agencies and lacked public participation. Livengood and Kunte (2014) claim NGO and CBO participation in BSUP projects, like those under VAMBAY, had no place in the decision-making process. The eligibility lists, house designs, specifications and terms and conditions are developed before NGOs and slum dwellers are invited to participate and bid on projects. Public and civic body 
participation in decision making of individual city development plans has remained a far cry despite the government rhetoric to encourage participation in the planning and decision-making phase.On the other hand lack of progress in capacity building among both ULBs and local governments to prepare and implement projects is striking. Most of the smaller ULBs do not have the capacity to prepare City Development Plan, but endorsed it notionally so that projects could be submitted to the Centre and funds could flow to the city (Sivaramakrishnan, 2011). The complex requirements set by RAY for technology-laden data collection and analysis before local plans and funding can be approved has been an exclusionary practice (Livengood and Kunte, 2014). This mirrors the technical requirements forced by JNNURM resulting in exclusion of most of the economically less advanced states. On the other hand, very little of the funds set aside for capacity building has been effectively used. In India individual states feel marginalised and lose appetite to drive ambitious programmes. Without active participation, the city Master Plans developed by participating state governments remain divorced from the urban planning process and lack connectivity. The decentralisation of housing delivery in Brazil is relativelymore advanced with incentives for setting-up state and municipal funds and councils, aimed at producing housing through a decentralised system. However, a high number of different 
programmes, funds, and delivery mechanisms made the housing system more complex and in turn less effective.

\section{Conclusion}

In the previous sections, housing approaches in Brazil and India are discussed which emphasise global trends and resistance to wholesome acceptance of enabling housing framework. Both countries have initiated state administered large-scale housing programmes within diverse institutional contexts quite in line with the emerging international trend in low-income housing delivery (Buckley et al, 2006). The processes perhaps include more issues and practices than we can cover here. The paper, therefore, draws attention to major observations. First, the continuous production of public housing in various forms to support the low-income households; and second, governments both in Brazil and India are adhering to enabling housing framework and the state is taking onto itself, the responsibility to provide for the poor. Thus, as one policy approach follows another the discursive space for the government policy doctrine acquires a layered structure, which contains elements of both provider and enabling approaches. Whilst these developments are still evolutionary they constitute an important basis for the eventual transition from enabler back to provider approach. 
As a minimum, this finding changes the presumption that a correct housing policy stance for urban poor in global South should be one of benign handover (to the market or private sector). Arguably on this basis, considerably more, not less, attention should be given to providing housing to the poor in these countries and structuring innovative subsidy programmes to do so. This trend is not common in Western countries. In the UK many local authorities have become house-builders again after borrowing cap was relaxed in recent years favouring bricks and mortar investment over individual subsidies. In a poignant advice to governments around the world, UN-Habitat (2016) imparts a clear message to avoid privatization of public rental housing where it converts it to private rental. The 'housing right' approach ('Back to the city' programmes in Brazil) also represents an important departure from the previous topdown approach of the federal government.

However, a complete reversion of the policy trend in both countries will still be some distance away at least for two reasons. First, because the production of a broader set of policies for housing has not been a production of one specific governance decision. Second, because programmes such as the MCMV and the JNNURM mobilised powerful private interests and broad coalitions that will create resistance to any policy reversals. Nevertheless, the pursuit of policy changes confronts many challenges 
within the complex dynamics of both supply and demand side environments that did not exist in provider era of the 1980s. There are now twice as many democratic governments in the world as two decades ago, and they are overwhelmingly more decentralised. Over time, the low-income housing market has seen a phenomenal growth and, is no longer a marginal investment, and is an economy of scale now that is capable of giving profitable returns. The former requires the plans and programmes to be inclusive, process-driven and responsive to the diverse local needs for which the government's role remains critical. The latter requires the government to organise the supply chain around delivering low-income housing, enabling procurement of building material at scale to facilitate construction industry, design right delivery model to encourages private sector participation at scale. Designing acceptable credit risk for housing financing and devising integrated programmes that bring everything together will be the lynchpin to the success.

\section{References}


Ahmed I (1998) Crisis of natural building materials and institutionalised self-help housing: The case of Grameen Bank in Bangladesh. Habitat International 22(4): 355374.

Ahluwalia I J, Kanbur R and Mohanty P K (2013) Urbanisation in India: Challenges, Opportunities and the Way Forward. London: Sage.

Angel, S 2000 Housing Policy Matters: A Global Analysis. New York: Oxford University Press.

Avritzer L (2007) Sociedade Civil, Instituições Participativas e Representação: Da Autorização à Legitimidade da Ação. Revista de Ciências Sociais, Rio de Janeiro, 50(3): 443 a 464.

Baindur, V, and Lalitha K (2009) Reengineering urban infrastructure: how the World Bank and Asian Development Bank shape urban infrastructure finance and governance in India. Bank Information Centre (2009). 
Barnhardt S, Field E and Pande_ R (2015) Moving to Opportunity or Isolation? Network Effects of a Randomized Housing Lottery in Urban India. NBER Working Paper No. 21419

Bermeo, N. (1990) Rethinking Regime Change, Comparative Politics 22, pp. 359- 377

Bhan G (2009) This is no longer the city I once knew: Evictions, the urban poor, and the right to the city in millennial Delhi Environment \& Urbanisation 29 (1), pp. 127-142.

Bonduki N (2014) Urban and Housing Policy from Lula to Dilma: Social Inclusion with Territorial Segregation pp 176-198. In Fábio de Castro, Kees Koonings, Marianne Wiesebron (eds) Brazil Under the Workers' Party, Palgrave MacMillan.

Buckley, R M, Singh, M and Kalarickal J (2007) Strategizing slum improvement in India: a method to monitor and refocus slum development programmes Global Urban Development $\quad$ Magazine $3(1), \quad$ available at http://www.globalurban.org/GUDMag07Vol3Iss1/Buckley\%20PDF.pdf, 24 pages. 
Buckley R M, Achilles Kallergis A and Wainer L (2016) The emergence of large-scale housing programs: Beyond a public finance perspective Habitat International 54: 199209.

Budds J, Teixeira P and SEHAB (2005) Ensuring the right to the city: pro-poor housing, urban development and tenure legalization in São Paulo, Brazil Environment \& Urbanization 17(1).

Cao, J A and Keivani R (2014) The limits and potentials of the housing market enabling paradigm: An evaluation of China's housing policies from 1998 to 2011 Housing Studies 29 (1): 44-68

Choguill C L (1997) Ten steps to sustainable urban infrastructure. The Urban Age 5(2): $22-23$

CREDAI (2013) Assessing the economic impact of India's real estate sector. Available at http://www.credai.org/sites/default/files/Assessing_the20economic_Impact_of_In dia_Real_Estate_Sector_Report.pdf

Accessed 03.06.16 
Datta K and Jones G (eds) (1999) Housing and finance in developing countries. London: Routledge.

De Soto H (2000) The Mystery of Capital. New York: Basic Books.

Durand-Lasserve A (1987) Land and housing in Third world cities Cities 4: 325-336.

Gilbert A (2004) Helping the poor through housing subsidies: lessons from Chile, Colombia And South Africa Habitat International 28(1): 13-40.

Instituto Brasileiro de Geografia e Estatística

(IBGE) $(1991,2000,2010)$ Census Demographico, IBGE

Islam N (1996) Sustainability issues in urban housing in a low-income country: Bangladesh Habitat International 20(3): 377-388.

Jones, G A and Ward P M (1995) The World Bank's new urban management programs: Paradigm shift or policy continuity? Habitat International 18(3):33-51.

Livengood A and Kunte K (2012) Enabling participatory planning with GIS: a case study 
of settlement mapping in Cuttack, India. Environment and Urbanization 24(1): 77-97

Mukhija V (2001) Enabling slum redevelopment in Mumbai: Policy paradox in practice Housing Studies 16(6):791-806.

Mukhija V (2004) The contradictions in enabling private developers of affordable Housing: A cautionary case from Ahmedabad, India Urban Studies 41(11): 2,231-2,244.

Nijman J (2008) Against the odds: Slum Rehabilitation in Neoliberal Mumbai, Cities 25(2): 73-85.

Ogu V I and Ogbuozobe J E (2001) Housing policy in Nigeria: Towards enablement of private housing development Habitat International, 25: 473-492.

Okpala, D C I (1994) Financing housing in developing countries: A review of the pitfalls and potentials in the development of formal housing finance systems Urban Studies 31(4): 1,571-1,586. 
Pasternak S and D' Ottaviano C (2014) Half a century of self-help in Brazil In: Bredenoord, J, Lindert P V and Smets P (eds) Affordable Housing in the urban global south: Seeking sustainable solutions, London: Earthscan, pp. 242-255.

Pasternak T S (1995) Squatter Settlements and Slums in Brazil: Twenty years of research and policy. In: Aldrich B. and Sandhu, R (eds) Housing the Urban Poor. London, Zed Books

Rahman M M (2001) Bastee eviction and housing rights: A case of Dhaka, Bangladesh Habitat International 25: 49- 67.

Ram P and Needham B (2016) The provision of affordable housing in India: Are commercial developers interested? Habitat International 55 : 100-108.

Rolnik R (2013) Late Neoliberalism: The financialization of homeownership and housing rights International Journal of Urban and Regional Research 37: 1058-1066. 
Rondinelli D (1990) Housing the urban poor in developing countries American Journal of Economics 49:153-166.

Sahu G, Zachariah Y and Sandipan B (2009) National level background document on urban issues and concerns. Retrieved from tiss-uirf.org/downloads/NLBD.pdf

Sengupta U (2006) Government intervention in public private partnership in housing in Kolkata Habitat International, 30(3): 448-461.

Sengupta U and Tipple A G (2007) Performance of public sector housing in Kolkata in the post reform milieu, Urban Studies 44(10): 2009-2027.

Sengupta U (2013) Inclusive Development? A State-Led Land Development Model in New Town, Kolkata Environment and Planning C 31(2): 357-376.

Sengupta U (2014) New frontiers and challenges In: Bredenoord, J, Lindert P V and Smets P (eds) Affordable Housing in the urban global south: Seeking sustainable solutions, London: Earthscan, pp. 137-153. 
Sivaramakrishnan K C (2011) The Revisioning Indian cities: The urban Renewal Mission. New Delhi: Sage Publications

Sivam A (2002) Constraints affecting the efficiency of the urban residential land market in developing countries: a case study of India. Habitat International 26(4):523-537.

Smets P (1995) Poor and in need for a house in the city! The government is there to help, but who is really helping who? Nagarlok xxviii(4):78-92.

Smets P (1997) Private housing finance in India: reaching down market? Habitat International 21(1):1-15.

Sharma P (2013) Urban Reforms under JNNURM- An Assessment. Journal Urban India, 33(II): 17-33.

Sud N (2017), State, Scale and Networks in the Liberalisation of India's Land, Environment and Planning C, 35 (1).

Tipple A G (1994), A matter of interface: The need for a shift in targeting housing interventions, Habitat International, 18(4):1-15. 
Tipple A G, Korboe D, Garrod G and Willis K (1999) Housing supply in Ghana: a study of Accra, Kumasi and Berekum. Progress in Planning 51(4): 253-324.

Tiwari P and Rao J (2016) Housing Markets and Housing Policies in India, ADBI Working Paper Series, ADB, Manila.

The Pioneer (2014) Poor show of housing plans under JNNURM exposed, The Pioneer, $21^{\text {st }}$ July.

Thornton G (2011) Appraisal of Jawaharlal Nehru National Urban Renewal Mission (JnNURM). Final Report - Volume I, Delhi: JNNURM.

United Nations (2014) World Urbanization Prospects, New York: UN.

UNCHS (1988) The global strategy for shelter to the Year 2000. Nairobi: UNCHS.

UN-Habitat (2001) The implications of globalization and privatization for the provision of and access to housing and urban development in the transition economies. In: Cities in a Globalizing World. London: Earthscan, pp. 88-93. 
UN-Habitat (2003) The Challenge of Slums: Global Report on Human Settlements. Nairobi: UN- Habitat.

UN-Habitat (2006) Enabling shelter strategies: Review of experience from two decades of implementation. Nairobi: UN-Habitat

UN-Habitat (2016) World Cities Report. Nairobi: UN publications

Valença F (1999) The lost decade and the Brazilian government's response in the 1990s. Journal of Developing Areas 33(1): 1-52

Valença, MM and Bonates M F (2010) The Trajectory of Social Housing Policy in Brazil: From the National Housing Bank to the Ministry of the Cities. Habitat International 34 (2)165-173

Wakely P (2014) Urban public housing strategies in developing countries: whence and whither paradigms, policies, programmes and projects. DPU60 Working Paper Series: Reflections N0.163/60 
Wang and Shao, (2010) Urban housing policy changes and challenges in China. In:

Doling J and Ronald R (eds)Housing East Asia: Socioeconomic and Demographic Challenges, London: Palgrave, pp. 40-70.

World Bank (1993) Public/private partnerships in enabling shelter strategies. Nairobi: UNCHS.

Yap K S (2015) The enabling strategy and its discontent: Low-income housing policies and practices in Asia, Habitat International. 54(3):166-172. 